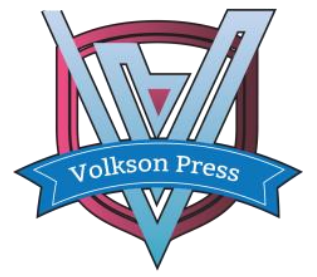

Contents List available at VOLKSON PRESS

Clean Water,Air\&Soil(CleanWAS)

DOI : http://doi.org/10.26480/cleanwas.01.2017.24.26

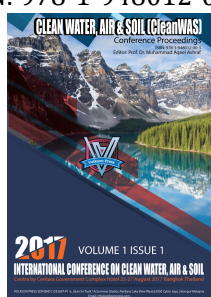

\title{
Research on low temperature environment self-regulating heating cable actively intervene in temperature field of the concrete curing
}

Liu $\operatorname{Lin}^{a b^{*}}$

\author{
${ }^{a}$ College of Resource and Civil Engineering, Northeastern University, Shenyang, 110000, China, ${ }^{b}$ Civil Engineering College, Shenyang jianzhu \\ University, Shenyang, 110000, China, \\ *Corresponding Author: Liu Lin, E-mail: liumumu118@163.com
}

This is an open access article distributed under the Creative Commons Attribution License, which permits unrestricted use, distribution, and reproduction in any medium, provided the original work is properly cited

\section{ARTICLE DETAILS}

\section{Article History:}

Received 02 october 2017 Accepted 06 october 2017 Available online 11 october 2017

Keywords:

Multi-parameter, custom defect discrimination threshold, Ultrasonic Testing

\section{ABSTRACT}

For several situations encountered in the detection, more complex internal structure, or testing data of smaller discreteness, data is less or more close, which is difficult to meet the conditions of use, that is concrete defect discrimination method of the ultrasonic testing method of current Chinese specifications. This paper aimed at existing in the detection of the above situation, studied the problems of the existing specifications defect discrimination method in solving the above situation, studied a multi-parameter custom critical defect evaluation method, respectively, studied on the use of the method in the testing data of smaller discreteness and complex internal structure. As detection is shown, first, this method can improve the accuracy in ultrasonic testing in such case, can effectively avoid the false negatives. IT makes defect detection rate of $90 \%$ or more. Second, according to the waveform of abnormalities detection data to determine defect discrimination threshold, it determines the defects of parts and the final defect result is more close. In addition, For conditions with less testing data, the use of other testing means, compares the ultrasonic testing results to obtain acoustic parameters, in order to set custom defect discrimination threshold, and reduce the number of false negatives.

\section{Introduction}

In cold regions, the winter lasts for half one year, and many large engineering projects should be for a number of years, it makes that a lot of concrete projects will be face winter construction problems. The curing method of concrete component in winter, including steam curing method, hydrothermal curing method, electrothermal curing method, infrared curing method, etc. But as the high-rise buildings and large volume concrete component is used, these traditional winter curing methods are limited by high construction layer and large components, etc, are becoming more and more unsuitable for winter construction site. A new concrete winter heating curing method, some heat source was buried into the concrete, concrete is directly heated. Through this method, to reduce concrete component damage caused by the temperature difference between inside and outside concrete, to overcome the space limitations to the construction site.

The common use of the shallow buried heat source heating curing method is electric heating cable. The electric heating cable includes constant temperature and variable temperature type. The Soviet engineers have used a diameter of $1.2 \mathrm{~mm}$ galvanizing line as the heating cable into a loop used in the heating curing of concrete. But constant temperature heating cable of power is not chance, it can't adjust the temperature automatically (Li et al 2009, Ni 2010). At present, a more advanced heating cable is a new kind of temperature control of heating materials, Self - regulating Heater. This material is widely used in tunnel leakage of freezing injury prevention, road frost crack, high-rise concrete structure winter curing projects, etc. This kind of material can restrict heating temperature automatically, can along with the temperature of the heating system to adjust output power without having to add other equipment (Wilson et al 1996, Yang et al 1994, Chao et al 2013).

\section{Problems}

Although the material has many advantages, but used in concrete structure has some problems. For example, the use of this material in concrete structure, it has not been carried out the corresponding temperature control theory research, there is no corresponding design method and construction measures, etc. So, based on the characteristics of temperature control in this material, a method of active temperature control is proposed, and the effect of the temperature control method, the temperature change law and other issues were studied.

\section{Active temperature control method 4}

The concrete construction quality depends on curing temperature in winter, so as to ensure the normal continuity for cement hydration reaction. Due to low temperature in winter, any measures is not used concrete is difficult to achieve specification requirement. So the built-in Self-regulating heating cable is used for heating the concrete. By heating cable establishing uniform temperature field, make the concrete normally complete hydration reaction (Liu et al 2015, Guo et al 2015). In this paper, take the initiative to intervene construction curing phase internal temperature field of concrete, under low temperature conditions using the built-in Self-regulating heating cable to improve the concrete temperature, to change the temperature field inside the concrete. Limiting the maximum temperature difference inside and outside, so as to effectively reduce the temperature gradient and reduce cracks.

\section{Materials and methodology}

\subsection{Specimen Design}

Experiments making $3 \mathrm{C} 30$ concrete blocks, the structure size is all $0.4 \times 0.4 \times 0.6 \mathrm{~m}$. The serial number is $1,2,3$. The heating cable was laid on the steel skeleton, layout mode is spiral wound. The structural form is shown in Table 1, and layout of heating cable see figure 1, the straight line is the bar, the curve is heating cable, the main difference of heating cable arrangement is whether the two ends are enclosing. The insulation layer includes a plastic cloth and rock wool. The rock wool thickness is $3 \mathrm{~cm}$.

Table 1. The heating cable arrangement of test blocks. 


\begin{tabular}{lllll}
\hline No. & $\begin{array}{l}\text { thickness } \\
\text { concrete } \\
\text { cover }\end{array}$ & length & spacing & $\begin{array}{l}\text { enclosing or } \\
\text { no }\end{array}$ \\
\hline 1 & $60 \mathrm{~mm}$ & $4.0 \mathrm{~m}$ & $200 \mathrm{~mm}$ & no \\
2 & $30 \mathrm{~mm}$ & $4.3 \mathrm{~m}$ & $200 \mathrm{~mm}$ & no \\
3 & $60 \mathrm{~mm}$ & $3.6 \mathrm{~m}$ & $250 \mathrm{~mm}$ & closed \\
\hline
\end{tabular}
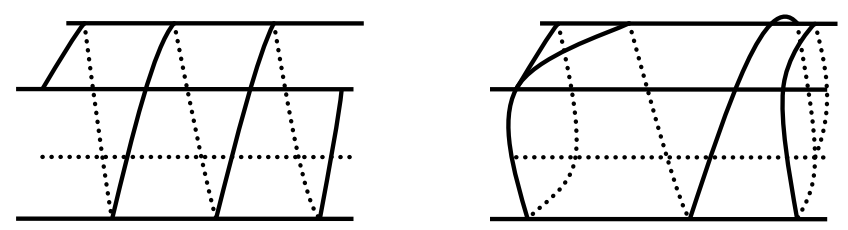

\section{Figure 1. Winding diagram}

Each block has 6 monitoring points, to record the temperature of concrete. Monitoring serial number rule is the first number indicates the number of the test block, and the second number is the number of the survey area, the letter $\mathrm{R}$ indicates that the monitoring points is in the block, the letter $\mathrm{M}$ indicates that the monitoring points is between the block and temperature protective layer, the letter $\mathrm{E}$ indicates that the monitoring points is the environment temperature, see figure 2. Section 1-1 is located in the middle of concrete block. Section 2-2 to the end of the concrete member distance is $10 \mathrm{~cm}$. Take block 1 as an example, the distance between the R11 and the structure edge is $5 \mathrm{~cm}, \mathrm{R} 13$ and R15 at the center of the section, R12 is in the middle of R11 and R13. M1 is located between the concrete block and the insulation layer. EI is ambient temperature. Before pouring the specimen, the two heating cable wrapped around the steel skeleton inside into two templates. Advance energized preheating, within a template to create the right temperature.

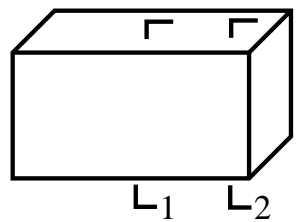

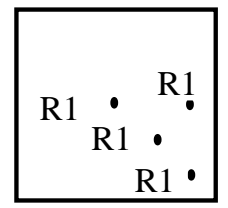

$1-1$

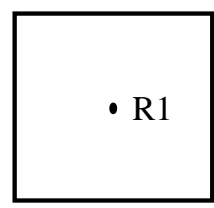

$2-2$
Figure 2. Concrete internal measure locations.

\subsection{Experimental Material}

The heating cable is 15DXW types of "medium temperature limit". The concrete is C30. The insulation layer includes a plastic cloth and rock wool. The temperature sensor is TFL-T-DZxx.

\subsection{The results of experimental}

No.1 and No.3 test blocks were heated 3 days, NO.2 test blocks were heated 7 days. By analyzing the temperature variation of monitoring points, whether exceed the specification requirements for temperature, Check the heating rate and cooling rate, to determine whether the provisions of the specification. Temperature change rule of the monitoring points shown below Table 2 .

The data analysis is as following:

(1)the template was preheated by the heating cable before pouring, and temperature is greater than $15^{\circ} \mathrm{C}$. The preheating temperature of No. 3 template is the most uniform and relatively high temperature. Because of the two ends are enclosing by heating cable.

(2)In the heating stage, the heating rate of every monitoring point is at around $3^{\circ} \mathrm{C}$, and trends are consistent. After stopping heating, the cooling rate of every monitoring point is at $1{ }^{\circ} \mathrm{C}$, and trends are consistent. But No.1 block, the concrete cover depth is the most thick, the heating cable arrangement distance is the shortest, that is to say, all the monitoring points are affected by the heating cable is the fastest and the most. So in the heating stage, the temperature rise rate is the largest, the time to reach the peak is the shortest. No.3 block of the concrete cover depth is consistent with No.1, but the heating belt arrangement distance is the longest. So in the heating stage, the temperature rise rate is the smallest, the time to reach the peak is the longest. But R35 is at the end of No.3 block, the No.3 block of the two ends are closed by heating cable, So R35 is compared with R15 and R25, the temperature rise rate is the largest, the time to reach the peak is the shortest.

(3)In the heating stage, the peak temperature is $63^{\circ} \mathrm{C}$. After reaching the peak, despite the continued heating, the point of the temperature remained is at around $61^{\circ} \mathrm{C}$.

(4)M1 is located between the concrete block and the insulation layer Through the comparison of the M1 point and other monitoring points, the M1 point is consistent with the temperature variation of other monitoring points. It can be seen that the heating method of heating effect is very significant.

\section{Table 2 The temperature change of the measuring points}

\begin{tabular}{|c|c|c|c|c|c|c|}
\hline $\begin{array}{l}\text { No } \\
\text {. }\end{array}$ & $\begin{array}{l}\text { preheatin } \\
\mathrm{g} \\
\text { temperat } \\
\text { ure } \\
\text { of } \\
\text { template }\end{array}$ & $\begin{array}{l}\text { heatin } \\
\text { g rate }\end{array}$ & $\begin{array}{l}\text { tim } \\
\text { e to } \\
\text { reac } \\
\mathrm{h} \\
60 \\
{ }^{\circ} \mathrm{C}\end{array}$ & $\begin{array}{l}\text { peak } \\
\text { temperat } \\
\text { ure }\end{array}$ & $\begin{array}{l}\text { stationar } \\
\text { y } \\
\text { temperat } \\
\text { ure }\end{array}$ & $\begin{array}{l}\text { cooli } \\
\text { ng } \\
\text { rate }\end{array}$ \\
\hline $\begin{array}{l}\mathrm{R} 1 \\
1\end{array}$ & 15.6 & $\begin{array}{l}3.7^{\circ} \mathrm{C} / \\
\mathrm{h}\end{array}$ & $12 \mathrm{~h}$ & $62^{\circ} \mathrm{C}$ & $61^{\circ} \mathrm{C}$ & $\begin{array}{l}1^{\circ} \mathrm{C} / \\
\mathrm{h}\end{array}$ \\
\hline $\begin{array}{l}\mathrm{R} 1 \\
2\end{array}$ & 17 & $\begin{array}{l}3.6^{\circ} \mathrm{C} / \\
\mathrm{h}\end{array}$ & $12 \mathrm{~h}$ & $63^{\circ} \mathrm{C}$ & $61^{\circ} \mathrm{C}$ & $\begin{array}{l}1^{\circ} \mathrm{C} / \\
\mathrm{h}\end{array}$ \\
\hline $\begin{array}{l}\mathrm{R} 1 \\
3\end{array}$ & 16.5 & $\begin{array}{l}3.6^{\circ} \mathrm{C} / \\
\mathrm{h}\end{array}$ & $\begin{array}{l}12.5 \\
\mathrm{~h}\end{array}$ & $63^{\circ} \mathrm{C}$ & $61^{\circ} \mathrm{C}$ & $\begin{array}{l}1^{\circ} \mathrm{C} / \\
\mathrm{h}\end{array}$ \\
\hline $\begin{array}{l}\text { R1 } \\
4\end{array}$ & 20 & $\begin{array}{l}3.6^{\circ} \mathrm{C} / \\
\mathrm{h}\end{array}$ & $11 \mathrm{~h}$ & $63^{\circ} \mathrm{C}$ & $61^{\circ} \mathrm{C}$ & $\begin{array}{l}1^{\circ} \mathrm{C} / \\
\mathrm{h}\end{array}$ \\
\hline $\begin{array}{l}\mathrm{R} 1 \\
5\end{array}$ & 15 & $\begin{array}{l}2.8^{\circ} \mathrm{C} / \\
\mathrm{h}\end{array}$ & $\begin{array}{l}16.5 \\
h\end{array}$ & $63^{\circ} \mathrm{C}$ & $61^{\circ} \mathrm{C}$ & $\begin{array}{l}1^{\circ} \mathrm{C} / \\
\mathrm{h}\end{array}$ \\
\hline M1 & 19 & $\begin{array}{l}3.4^{\circ} \mathrm{C} / \\
\mathrm{h}\end{array}$ & $12 \mathrm{~h}$ & $63^{\circ} \mathrm{C}$ & $61^{\circ} \mathrm{C}$ & $\begin{array}{l}1^{\circ} \mathrm{C} / \\
\mathrm{h}\end{array}$ \\
\hline $\begin{array}{l}\mathrm{R} 2 \\
1\end{array}$ & 18 & $\begin{array}{l}2.9^{\circ} \mathrm{C} / \\
\mathrm{h}\end{array}$ & $\begin{array}{l}14.5 \\
\mathrm{~h}\end{array}$ & $63^{\circ} \mathrm{C}$ & $61^{\circ} \mathrm{C}$ & $\begin{array}{l}1^{\circ} \mathrm{C} / \\
\mathrm{h}\end{array}$ \\
\hline $\begin{array}{l}\mathrm{R} 2 \\
2\end{array}$ & 15 & $\begin{array}{l}2.9^{\circ} \mathrm{C} / \\
\mathrm{h}\end{array}$ & $\begin{array}{l}15.5 \\
\mathrm{~h}\end{array}$ & $63^{\circ} \mathrm{C}$ & $61^{\circ} \mathrm{C}$ & $\begin{array}{l}1^{\circ} \mathrm{C} / \\
\mathrm{h}\end{array}$ \\
\hline $\begin{array}{l}\mathrm{R} 2 \\
3\end{array}$ & 15 & $\begin{array}{l}2.9^{\circ} \mathrm{C} / \\
\mathrm{h}\end{array}$ & $16 \mathrm{~h}$ & $63^{\circ} \mathrm{C}$ & $61^{\circ} \mathrm{C}$ & $\begin{array}{l}1^{\circ} \mathrm{C} / \\
\mathrm{h}\end{array}$ \\
\hline $\begin{array}{l}\mathrm{R} 2 \\
4\end{array}$ & 20 & $\begin{array}{l}2.9^{\circ} \mathrm{C} / \\
\mathrm{h}\end{array}$ & $14 \mathrm{~h}$ & $63^{\circ} \mathrm{C}$ & $61^{\circ} \mathrm{C}$ & $\begin{array}{l}1^{\circ} \mathrm{C} / \\
\mathrm{h}\end{array}$ \\
\hline $\begin{array}{l}\text { R2 } \\
5\end{array}$ & 14 & $\begin{array}{l}2.5^{\circ} \mathrm{C} / \\
\mathrm{h}\end{array}$ & $18 \mathrm{~h}$ & $62^{\circ} \mathrm{C}$ & $60^{\circ} \mathrm{C}$ & $\begin{array}{l}1^{\circ} \mathrm{C} / \\
\mathrm{h}\end{array}$ \\
\hline $\begin{array}{l}\text { R3 } \\
1\end{array}$ & 19 & $\begin{array}{l}2.4^{\circ} \mathrm{C} / \\
\mathrm{h}\end{array}$ & $17 \mathrm{~h}$ & $63^{\circ} \mathrm{C}$ & $61^{\circ} \mathrm{C}$ & $\begin{array}{l}1^{\circ} \mathrm{C} / \\
\mathrm{h}\end{array}$ \\
\hline $\begin{array}{l}\text { R3 } \\
2\end{array}$ & 19 & $\begin{array}{l}2.5^{\circ} \mathrm{C} / \\
\mathrm{h}\end{array}$ & $\begin{array}{l}16.5 \\
h\end{array}$ & $63^{\circ} \mathrm{C}$ & $61^{\circ} \mathrm{C}$ & $\begin{array}{l}1^{\circ} \mathrm{C} / \\
\mathrm{h}\end{array}$ \\
\hline $\begin{array}{l}\text { R3 } \\
3\end{array}$ & 19 & $\begin{array}{l}2.55^{\circ} \mathrm{C} \\
/ \mathrm{h}\end{array}$ & $16 \mathrm{~h}$ & $63^{\circ} \mathrm{C}$ & $61^{\circ} \mathrm{C}$ & $\begin{array}{l}1^{\circ} \mathrm{C} / \\
\mathrm{h}\end{array}$ \\
\hline $\begin{array}{l}\text { R3 } \\
4\end{array}$ & 19 & $\begin{array}{l}2.56^{\circ} \mathrm{C} \\
/ \mathrm{h}\end{array}$ & $\begin{array}{l}16.5 \\
\mathrm{~h}\end{array}$ & $63^{\circ} \mathrm{C}$ & $61^{\circ} \mathrm{C}$ & $\begin{array}{l}1^{\circ} \mathrm{C} / \\
\mathrm{h}\end{array}$ \\
\hline $\begin{array}{l}\text { R3 } \\
5\end{array}$ & 16 & $\begin{array}{l}2.8^{\circ} \mathrm{C} / \\
\mathrm{h}\end{array}$ & $16 \mathrm{~h}$ & $63^{\circ} \mathrm{C}$ & $61^{\circ} \mathrm{C}$ & $\begin{array}{l}1^{\circ} \mathrm{C} / \\
\mathrm{h}\end{array}$ \\
\hline
\end{tabular}

4.4 The comparative analysis of the temperature curves of the three test blocks of the same position

By analyzing the temperature variation of the three test blocks of the same position, the influence of the thickness of steel bar protection layer, wire spacing, and the closed end by wire is analyzed.

Figure 3 shows the temperature curves of the three test blocks of the same position, including three positions, such as center, side angle.

Figure (3a) shows that R11 heating is the fastest. The peak temperature of R31 is the highest. After entering the stationary phase, R31 and R11 curves decreased significantly compared with R21. NO.1 and NO.3 of the 
reinforcement layer thickness is $60 \mathrm{~mm}$, while NO.2 is $30 \mathrm{~mm}$. Although N0.2 use of the wire is the longest, but the heat dissipation is faster than NO.1, so the R21 heating rate is slower than R11. Because of the largest wire spacing, R31 is the latest to reach peak. But the ends of the NO.3 are wound with wires, and the peak temperature is the highest.

Figure (3b) shows that R13 heating is the fastest. No.2 of wire is the longest, but the steel protective layer is thin, the heat dissipation is fast, so the temperature reached the peak time is slower than NO.1. In addition, with the function of water temperature gradually weakened, the central temperature of NO.2 decreased obviously.

Figure (3c) shows that R15, R25, R35 located in the distance from the end of the $10 \mathrm{~cm}$, the heat dissipation is faster than the internal test block. But the ends of the NO.3 are wound with wires, and the peak temperature of R35 is the highest.

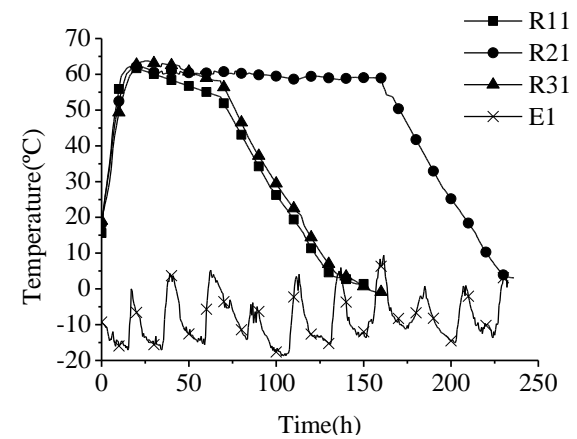

(3a)

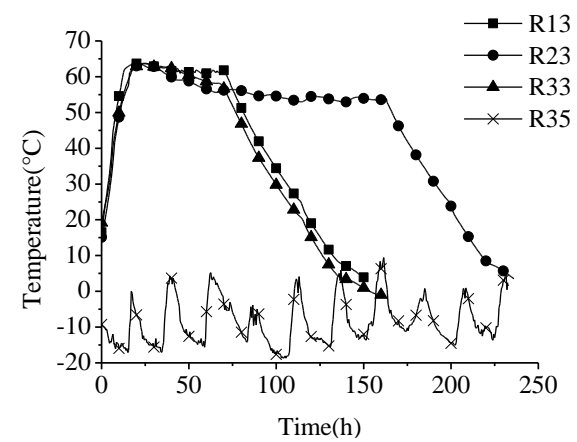

(3b)

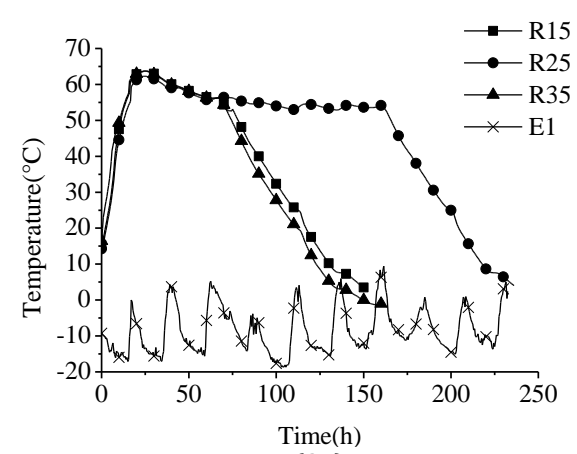

(3c)

Figure 3. The comparative analysis of the temperature curves of the three test blocks of the same position.

(3a) Under the influence of environmental temperature change, R11, R21, R31 of the temperature change curve.

(3b)Under the influence of environmental temperature change, R13, R23, R33 of the temperature change curve.

(3c) Under the influence of environmental temperature change, R15, R25, R35 of the temperature change curve.

\subsection{Rebound method test results}

Using rebound method to measure every test block for 3 days, 7 days, 28 days compressive strength (Chinese Standards 2010). No.1 and No.3 test blocks were heated 3 days, NO.2 test blocks were heated 7 days. The strength of all test block is to meet the requirements, see Figure 4 , and the test blocks were heated 3 days is able to meet the concrete curing requirements.

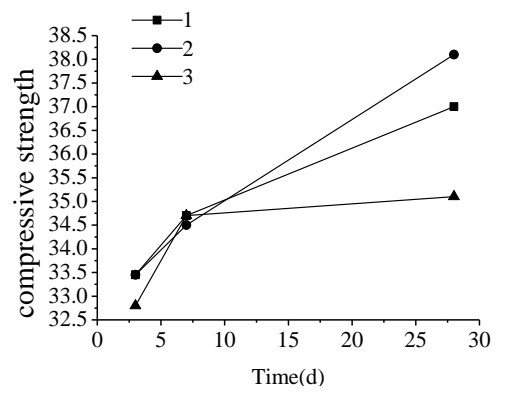

Figure 4. The rebound method detection results of test blocks.Conclusions

In this paper, the effects of electric heating on the temperature field are studied by experiments. The feasibility of the built-in Self-regulating heating cable used for curing the concrete is proved by experiments. The factors affecting the curing temperature were analyzed in the data of different groups.

1. According to the experimental data, the main factors affecting the temperature of the heating rate and the peak temperature of concrete specimen under the same insulation condition include the length of the electric heating and the distance between the wire and the concrete surface.

2. Experimental results show that the critical strength of concrete can be reached at 3 days. With increasing the heating time, the concrete strength increases, but the effect is not significant.

3. By comparing the temperature curve, the trend of the temperature curve of the measuring point is the same, the difference is very small, which shows that the temperature field is uniform and the temperature difference is small.

4. The block boundary corners should be arranged Self-regulating heating cable, avoid corner of frost damage and equilibrium temperature field, the tension of the time delay and reduce tension.

\section{References}

China Engineering Construction Standardization Association standard. (2000). technological specification for inspection of concrete defects by ultrasonic method, [CECS 21:2000], Beijing.

Chao, W. Q., \& Xia, Z. L. (2013). Concrete construction technology of the super large bridge pier column and the winter period. High Way, 8, 5961.

Guo, J.B., Liu, L., \& Wang, Q. (2014). Application self-regulating heating cable curing of concrete in winter," Civil, Architectural and Hydraulic Engineering(ICCAHE) ,1531-1535.

Li, H.H., \& Huang, Y.(2009) . Construction technique of concrete curing by resistant wire pre-embeded in concrete in frigid cold area. Architecture Technology, 40(9), 806-809.

Liu, Lin., \& Guo, J.B. ( 2015) Application of self-regulating heater in concrete construction. Value Engineering, 34, 121-122.

Ni, F. (2010). Curing method of internally installed and circulated electrical heating applied to concrete construction in winter season for baltic pearl project. Building Construction, 32(7), 687-689.

Wilson, J.G., \& Gupta, N.K.( 1996). Analysis of power distribution in reinforced concrete during accelerated curing using electroheat. In Electric Power Applications, IEE Proceedings, 143(2), 172-176.

Yang, W.H., Ding, X.B., \& Zhu, Z.H. (1994). On the thermal stability behaviour of self-temperature-limiting heating strip. Journal of China University Of Science And Technology, 24, 355-360. 